\begin{tabular}{|l|l|c|c|c|}
\hline \multicolumn{1}{|c|}{ Submission } & \multicolumn{1}{|c|}{ Review Process } & Revised & Accepted & Published \\
\hline $25-02-2020$ & $28-02$ s/d 25-03- & $26-03-2020$ & $30-12-2019$ & $01-04-2020$ \\
& 2020 & & & \\
\hline
\end{tabular}

Ampera: A Research Journal on Politics and Islamic Civilization, Vol. 1 No. 2, April 2020 (81-92)

Published by: Politik Islam UIN Raden Fatah Palembang

\title{
Hamas dan Fatah: Tekanan Ideologi dalam Membebaskan Palestina
}

\section{Badra Jultouriq Rahman}

\author{
Jurusan Hubungan Internasional, Universitas Padjadjaran \\ Email: badra18001@mail.unpad.ac.id
}

\begin{abstract}
Hamas and Fatah are the two dominant Palestinian political parties that have the same goal of freeing Palestinians from Israeli occupation. But there are ideological differences between Hamas and Fatah, Fatah with secular nationalist ideology while Hamas with Islamic ideology. The difference in ideology is considered to be the cause of the lack of cooperation between the two to free Palestine from Israeli occupation. This paper seeks to answer the question of why Hamas and Fatah did not unite to free Palestine from Israeli occupation when both have the same goal, whether differences in ideology are the main obstacle for Hamas and Fatah not to unite to liberate Palestine. In this paper the authors use the theory of conflict resolution and descriptive methods. The results of this study indicate that ideology is indeed one of the reasons Hamas and Fatah are not cooperating, because these two ideologies are in conflict with each other, but the historical conflict factor between Hamas's predecessors, the Muslim Brotherhood and Fatah has affected the inability of Hamas and Fatah to cooperate in efforts to liberate Palestine because differences of opinion in addressing resistance to Israel, then coupled with the disappointment of Hamas against Fatah which was hit by the issue of corruption and abuse of power, and Hamas considers Fatah to recognize the existence of Israel after signing the Oslo Declaration. Furthermore, it is hoped that this article can be used as a reference and comparison material for similar research.
\end{abstract}

Keywords: Fatah, Hamas, ideological pressure

\begin{abstract}
ABSTRAK
Hamas dan Fatah merupakan dua partai politik dominan Palestina yang memiliki tujuan yang sama yaitu membebaskan Palestina dari pendudukan Israel. Namun terdapat perbedaan ideologi antara Hamas dan Fatah, Fatah dengan ideologi nasionalis sekular sedangkan Hamas dengan ideologi Islam. Perdedaan ideologi tersebut dianggap menjadi penyebab tidak adanya kerja sama antara keduanya untuk membebaskan Palestina dari
\end{abstract}


pendudukan Israel. Tulisan ini berusaha menjawab pertanyaan tentang mengapa Hamas dan Fatah tidak bersatu untuk membebaskan Palestina dari pendudukan Israel padahal keduanya memiliki tujuan yang sama, apakah perbedaan ideologi menjadi hambatan utama Hamas dan Fatah untuk tidak bersatu membebaskan Palestina. Pada tulisan ini penulis menggunakan teori resolusi konflik dan metode deskriptif. Hasil penelitian ini menunjukan bahwa ideologi memang menjadi salah satu penyebab Hamas dan Fatah tidak bekerja sama, karena kedua ideologi ini saling berlawanan, namun faktor sejarah konflik antara pendahulu Hamas yaitu Ikhwanul Muslim dengan Fatah berpengaruh kepada tidak mampunya Hamas dan Fatah untuk bekerja sama dalam upaya membebaskan Palestina karena perbedaan pandangan dalam menyikapi perlawanan terhadap Israel, kemudian ditambah dengan kekecewaan Hamas terhadap Fatah yang dilanda isu korupsi dan penyelewengan kekuasaan, dan Hamas menganggap Fatah mengakui eksistensi Israel setelah menandatangi Deklasari Oslo. Selanjutnya diharapkan semoga tulisan ini dapat dijadikan sebagai bahan rujukan dan perbandingan bagi penelitian sejenis.

Keywords: Fatah, Hamas, tekanan ideologi

\section{PENDAHULUAN}

Dengan kondisi Palestina yang terjajah oleh Israel menyebabkan munculnya gerakan sosial dari beberapa kelompok masyarakat Palestina sebagai bentuk penolakan kehadiran negara Israel di tanah Palestina. Gerakan sosial sendiri merupakan jaringan interaksi informal antara sejumlah individu yang membentuk suatu kelompok berdasarkan identitas yang sama dan terlibat dalam sebuah konflik politik atau budaya (Diani, 1992). Kelompokkelompok yang lahir karena kondisi penjajahan di Palestina tersebut yaitu Fatah dan Hamas, walaupun sebelumnya sudah ada gerakan perjuangan untuk memperjuangkan kemerdekaan Palestina seperti Organisasi Pembebasan Palestina (PLO), namun Fatah dan Hamas bediri atas dasar ketidak puasan kepada berbagai macam bentuk perjuangan yang sudah dilakukan sebelumnya.

Kedua gerakan perlawanan dan partai politik yang paling dominan di Palestina ini justru terlibat konflik padahal keduanya memiliki tujuan yang sama, yaitu membuat Palestina merdeka dari penjajahan Israel. Jika melihat latar belakang organisasi pergerakan Hamas, mereka merupakan cabang dari gerakan Ikhwanul Muslimin (IM) di Mesir yang berdiri pada 14 Desember 1987 (Prabowo, 2013). Hamas menilai bahwa usaha-usaha diplomasi yang telah dilakukan oleh beberapa gerakan perlawanan Palestina terhadap Isreal hanya merugikan rakyat Palestina saja dan malah memperkuat posisi Israel, selain itu Hamas tidak setuju dengan strategi dan cara yang dilakukan oleh Fatah dalam mewujudkan kemerdekaan Palestina (Irwan Abdallah, Setyawati, \& Mutiah, 2015).

Hamas sendiri memiliki tujuan untuk membebaskan Palestina dari pendudukan Israel dan membentuk negara Islam di wilayah yang sekarang dikuasi oleh Israel, demikian juga dengan Fatah (Dewi, Sudrajat, \& Miftahuddin, 2008). Fatah yang lebih dulu terbentuk sudah melakukan berbagai cara untuk mewujudkan Palestina yang merdeka, dari gerakan bersenjata hingga berjuang di meja perundingan sudah dilakukan oleh Fatah. Hal itu membuat Fatah berubah menjadi kekuatan yang sangat dominan di Palestina di tahun 1960-an karena berhasil memenangkan Perang Enam Hari. Namun 
setelah Hamas berhasil memenangkan kursi Parlemen pada tahun 2006, dominasi Fatah di parlemen menjadi turun, setelah itu sering terjadi konflik antara Hamas dan Fatah.

Penulis tertarik untuk mengkaji Hamas dan Fatah karena kedua partai politik tersebut memiliki tujuan yang sama yaitu membentuk negara Palestina ditengah konflik yang terjadi dengan Israel. Jika dilihat dari tujuan Fatah dan Hamas, mereka sama-sama berkeinginan untuk membebaskan Palestina dari penjajahan Israel, namun mengapa kedua kubu ini sering terlibat konflik dan tidak adanya usaha kerja sama untuk membebaskan Palestina, padahal situasi di Palestina sedang dikuasi oleh Israel. Dalam melakukan pembacaan terhadap pengaruh ideologi sebagai tekanan dalam memerdekaan Palestina yang membuat Fatah dan Hamas tidak melakukan kerja sama untuk membebaskan Palestina dari pendudukan Israel, penulis melakukan analisis dengan menggunakan teori resolusi konflik. Dimana cara mengatasi sebuah konflik bisa dengan berbagai macam cara seperti rekonsiliasi dan menyelesaikan suatu masalah bersamasama.

Berdasarkan uraian tersebut, penulis tertarik untuk menelisik lebih dalam, apakah tekanan ideologi menjadi faktor utama Hamas dan Fatah tidak dapat bekerja sama membebaskan Palestina dari tangan Israel?. Pertanyaan tersebut muncul karena peneliti menemukan di beberapa tulisan yang membahas Hamas dan Fatah bahwa mereka selalu menyinggung perbedaan ideologi yang dimiliki kedua fraksi tersebut sebagai alasan mengapa mereka tidak berjalan beriringan. Beberapa pengkaji Timur Tengah mengatakan bahwa ketidaksepahaman Hamas dengan Fatah berasal dari perbedaan mendasar yaitu ideologi (Basyuni, 2015; Abdallah, 2015; Sangidu, 2015; Setyawati; 2015).

Peneliti setuju dengan pendapat tersebut, namun perbedaan ideologi keduanya bukan penyebab utama dan satu-satunya dari perpecahan antara Hamas dan Fatah sehingga keduanya tidak berjalan beriringan dan melakukan kerja sama, peneliti menemukan ada beberapa penyebab lainnya, yaitu: (1) Perbedaan cara dalam usaha untuk memerdekakan Palestina, Hamas memilih bergerilya dengan mengangkat senjata, sedangkan Fatah yang bergabung dengan PLO lebih memilih jalur diplomasi dan meninggalkan perjuangan melalui kekuatan militer untuk mengusir Israel, (2) isu korupsi dan penyelewengan kekuasaan yang menerpa Fatah setelah menandatangani kesepakatan Deklarasi Oslo II (Burdah, 2008), (3) kesepakatan yang ditanda tangani oleh Fatah dan Israel pada Deklarasi Oslo dianggap oleh Hamas sebagai pengakuan Palestina terhadap Israel yang mana bertentangan dengan pendirian Hamas (Prabowo, 2013). Namun jauh sebelum semua itu menjadi penyebab Hamas dan Fatah tidak bekerja sama, pada tahun 1967, pendahulu Hamas yaitu Ikhwanul Muslimin di Palestina pernah bersatu dengan Fatah untuk melawan Israel. Namun pada tahun 1970-an mereka memutuskan untuk berjalan sendiri-sendiri karena adanya perbedaan pandangan dalam perjuangan membebaskan Palestina dari pendudukan Israel, Ikhwanul muslimin memilih untuk tidak terlibat perang, mereka lebih memilih untuk memperbaiki kualitas manusia Palestina melalui pendidikan, sedangkan Fatah memilih jalur perang (Bachtiar, 2006). Oleh karena itu tidak heran jika Hamas yang merupakan titisan dari Ikhwanul Muslimin tidak melakukan kerja sama dengan Fatah.

\section{TINJAUAN LITERATUR}

Konflik menurut Pruitt dan Rubin merupakan persepsi terhadap perbedaan kepentingan atau suatu kepercayaan yang beranggapan bahwa aspirasi pihak-pihak yang berkonflik tidak dapat menemui titik temu yang sepaham (Pruitt \& Rubin, 2009). Dari definisi tersebut konflik dapat dipahami sebagai interaksi sosial yang disebabkan oleh 
pertentangan antara kehendak atau nilai-nilai yang dipegang seperti ideologi maupun tujuan yang menciptakan kondisi ketidak nyamanan individu ataupun kelompok tertentu. Dari beberapa penelitian terdahulu penulis menemukan adanya eksistensi gerakan kelompok masyarakat Palestina sebelum Hamas dan Fatah yaitu Organisasi Pembebasan Palestina (PLO), yang merupakan hasil bentukan dari Liga Arab (Dewi, Sudrajat, \& Miftahuddin, 2008). Namun belum pernah terjadi konflik sesama gerakan perjuangan Palestina seperti yang terjadi antara Fatah dan Hamas. Dari berbagai macam bacaan, penulis menemukan penyebab konflik Fatah dan Hamas yang hanya berfokus kepada faktor perbedaan ideologi yang mereka miliki saja namun ternyata bukan faktor ideologi saja yang membuat keduanya tidak bekerja sama untuk membebaskan Palestina dari Israel, namun ada beberapa faktor lainnya yang membuat kedua kubu berkonflik satu sama lain.

Dalam sebuah konflik yang terjadi, baik itu antara invidu dengan individu, individu dengan kelompok, kelompok dengan kelompok, bahkan negara dengan negara untuk menyelesaikan konflik yang terjadi dibutuhkan sebuah resolusi. Resolusi konflik menurut Weitzman \& Weitzman adalah menyelesaikan masalah bersama-sama sehingga mereka yang berkonflik akan membuat keputusan bersama. Penyelesaian masalah terhadap sebuah konflik juga berkaitan erat dengan pengambilan keputusan bahkan dianggap menjadi bagian yang sama. (Fatimah, 2019)

Penyelesain konflik menurut Weitzman \& Weitzman mengarah kepada penyelesain konflik yang lebih bersifat kerja sama, mereka membagi tahapan penyelesain konflik menjadi 4 tahapan secara umum : (1) mendiagnosis konflik, (2) mengidentifikasi solusi alternatif, (3) mengevaluasi dan memilih solusi yang dapat diterima bersama, dan tahapan terakir adalah (4) berkomitmen untuk mengambil keputusan dan mengimplementasikan keputusan yang sudah disepakati. (Deutsch, Coleman, \& Marcus, 2006). Berdasarkan konsep resolusi konflik dari Weitzman \& Weitzmen, langkah pertama yang perlu dilakukan dalam penyelesaian konflik adalah mendiagnosa konflik dengan cara menemukan sebab-sebab terjadinya perselisihan kedua pihak atau dengan cara mengidentifikasi masalah. Sama halnya dengan konflik yang terjadi antara Hamas dan Fatah, untuk menyelesaikan konflik tersebut sangat penting sekali untuk mengetahui akar permasalahan mengapa mereka berkonflik.

Tahap kedua dalam menyelesaikan konflik yaitu mengedintifikasi solusi alternatif dengan cara diskusi. (Mokhtar, 2019) Dalam tahap kedua ini, pihak-pihak yang berkonflik diharapkan memiliki fokus untuk menemukan jalan keluar dan meredam emosi, hal tersebut sejalan dengan penjelesan mengenai bagaimana cara menyelesaikan konflik menurut Rubin, Pruit, dan Kim yang menjelaskan bahwa penyelesaian konflik dapat tercapai apabila solusi dapat diterima oleh kedua pihak yang bersangkutan (Pruitt \& Rubin, 2009). Sama halnya dengan Hamas dan Fatah yang beberapa kali sempat melakukan perundingan atau usaha-usaha damai yang di mediatori oleh Mesir, dengan bertemunya kedua pihak yang bertikai diharapkan adanya sebuah solusi yang disepakati bersama-sama.

Tahap ketiga yaitu memilih solusi atau mengevaluasi solusi yang sudah ditemukan untuk menyelesaikan konflik yang dapat disepakati bersama dengan kata lain melakukan negosiasi, ditahap ini pertimbangan kembali atas solusi-solusi yang sudah ditemukan pada tahapan sebelumnya secara cepat perlu dilakukan karena akan mempengaruhi kedua pihak pada tahapan selanjutnya, apakah mereka sepakat dan mampu mengimplementasikan solusi yang telah disepakati atau tidak. Evaluasi terhadap solusi yang sudah ditemukan dirasa perlu untuk mencapai kesepakatan antara kedua pihak 
yang berkonflik hingga pada akhirnya mereka dapat membuat keputusan.

Pengambilan keputusan sebaiknya dilakukan pada masa proses penyelesain masalah, pada proses ini masing-masing pihak yang berkonflik akan membuat keputusan, beberapa ahli berpandangan bahwa setiap pihak yang terlibat adalah sebagai pengambil keputusan (seperti, Kahneman, 1992; Mann, 1992), sedangkan yang lainnya berpandangan bahwa proses resolusi konflik merupakan sebuah pengambilan keputusan bersama (seperti, Bennet, Tait, dan Macdonagh; 1994). Namun pada akhirnya kembali lagi kepada keputusan kedua pihak yang berkonflik, apakah menyetujui solusi yang ditemukan atau tidak. Sama halnya yang dialami oleh Hamas dan Fatah, keduanya sempat mencoba berbagai macam usaha untuk berdamai walaupun mengalami kegagalan sebelum mencapai kesepakatan rekonsiliasi pada tahun 2017.

Tahap terkahir dalam menyelesaikan konflik menurut Weitzman \& Weitzman yaitu berkomitmen untuk mengambil keputusan dan yang terpenting adalah mampu mengimplementasikan keputusan yang sudah disepakati, hal ini sangat penting bagi berlangsungnya keadaan damai kedua pihak setelah menyepakati solusi yang akan diterapkan dan dilaksanakan oleh pihak yang menyepakatinya, karena jika tidak, maka keadaan damai tersebut akan berubah menjadi keadaan konflik kembali karena kedua pihak atau salah satu pihak yang bersepakat tidak mengimplementasikan solusi yang sudah disepakati. Sama halnya dengan Hamas dan Fatah yang akhirnya pada tanggal 12 Oktober 2017 di Kairo, Mesir berkomitmen untuk berdamai dengan melakukan rekonsiliasi. Berdasarkan pemaparan dari berbagai macam tahapan untuk mencapai resolusi konflik tersebut pada konflik yang terjadi antara Hamas dan Fatah, penulis melihat keduanya telah melakukan tahapan-tahapan resolusi konflik menurut Weitzman \& Wietzmen dari tahap pertama hingga tahapan yang terkahir.

\section{METODE PENELITIAN}

Tulisan ini memfokuskan pada kajian pustaka. Dalam kajian tersebut, penulis membaca karya-karya yang terkait dengan tema yang diangkat yaitu Hamas dan Fatah dengan lebih fokus terhadap ideologi dan gerakan perjuangan yang dimiliki kedua gerakan pembela Palestina tersebut dan pengarunya terhadap hubungan keduanya. Sumber-sumber lain dalam bentuk berita dan artikel yang terkait akan menjadi data penunjang dalam tulisan ini untuk memahami lebih jauh mengenai ideologi Hamas dan Fatah serta pengaruhnya terhadap pola perilaku dan interaksi keduanya.

Metode deskriptif merupakan metode penelitian yang digunakan untuk menggambarkan dan memberi uraian terhadap masalah atau gejala yang sedang diteliti dengan mendeskripsikan nilai variabel yang ada dan tidak menghubungkan atau membandingkan dengan variabel yang lain.

Tahap pertama, peneliti mencari dan mengumpulkan sumber sumber literatur dari jurnal, artikel atau berita yang telah dipublikasikan dan terpercaya. Tahap kedua, peneliti nengidentifikasi masalah dan gejala yang terjadi secara rinci dan memeriksa praktik yang berlangsung secara detail. Identifikasi didapat dari banyak sumber dengan memperhatikan keselarasan dan keakuratan berita yang dibaca. Tahap ketiga, mengakumulatifkan bukti-bukti berupa perjanjian atau aktivitas politik yang dilakukan guna memberikan bukti dari isu yang ada sehingga pembaca dapat melihat realita yang terjadi dan dapat mengambil kesimpulan dari isu tersebut. Tahap ini menjadi teknik penelitian yang terakhir. 


\section{HASIL DAN PEMBAHASAN}

\section{Ideologi dan Pergerakan Hamas}

Sejarah terbentuknya gerakan Hamas berawal dari protes atas ketidak puasan sebagian dari masyarakat Palestina terhadap perjuangan melalui jalur diplomasi seperti yang dilakukan oleh Organisasi Pembebasan Palestina (PLO) dan Fatah yang dipimpin oleh Yasser Arafat. Namun terbentuknya Hamas bukan semata-mata berawal dari seruan yang dilakukan oleh Syeikh Ahmad Yasin, ketika ia meminta rakyat Palestina untuk bersatu melawan militer Israel pada 14 Desember 1987 di Gaza. Namun gerakan ini sudah ada pada tahun 1930-an yang dilakukan oleh Ikhwanul Muslimin (IM) di Palestina yang kemudian dititiskan kepada Hamas.

Stuktur organisasi Hamas memiliki basis tarbiyah dan memiliki badan pelaksana (Maqtab Qiyadi) yang melaksanakan program dilapangan, badan ini terbagi menjadi tiga divisi, yaitu divisi keamanan, militer, dan politik. Divisi keamanan bertugas untuk mengumpulkan informasi intelejen Israel, sedangkn divisi militer bertugas mengumpulkan kekuatan masa dan menyerang Israel, yang terakhir adalah divisi politik yang bertugas untuk memberikan pernyataan, publikasi, dan menyelesaikan berbagai macam permasalahan politik yang ada.

Hamas yang merupakan turunan dari organisai Ikhwanul Muslimin (IM) yang lahir di Mesir pada tahun 1928 dan memiliki ideologi Islam mewariskan ideologinya kepada Hamas. Ideologi Islam yang dipegang oleh Hamas membentuk tujuan mereka yang menginginkan berdirinya negara Islam Palestina yang merdeka dan berdaulat. Ditambah dengan kerangka "Pan Islamisme" yang melibatkan seluruh umat muslim dunia untuk bersama-sama melawan Israel, kerangka tersebut memperkuat ideologi Islam yang dianut oleh Hamas, serta diperkuat oleh pernyataan yang dikeluarkan oleh Hamas, yaitu

"Hari Penghakiman tidak akan terjadi sampai Muslim memerangi dan membunuh mereka. Kemudian, orang-orang Yahudi akan bersembunyi di balik batu dan pohonpohon, dan batu-batu dan pohon-pohon akan berteriak: 'O Muslim, ada orang Yahudi yang bersembunyi di belakangku, datang dan bunuh dia.' "Piagam Hamas, Pasal 7." Israel akan ada dan akan terus ada sampai Islam akan melenyapkannya, sama seperti ia melenyapkan orang lain sebelumnya. "Piagam Hamas, Pembukaan. (Santis, 2008).

Ideologi Islam atau islamisme diartikan sebagai ideologi politik yang menggunakan Islam sebagai pegangan para penganutnya dalam berpolitik, ideologi ini memiliki karakter khusus yaitu setiap tindakan politik yang diambil berkiblat kepada alqur'an dan hadist. Dalam praktiknya ketika berpolitik, para kaum islamis menafsirkan ayat-ayat Al-Qur'an atau hadist sesuai dengan kepentingan politik mereka, dan ideologi ini juga menolak atau berlawanan dengan ideologi sekular yang merupakan ideologi politik Fatah. Ada beberapa macam alasan mengapa mereka menolak sekularisme, menurut Bassam Tibi mereka menolak karena ketidak tahuan mereka mengenai konsep dan signifikansi dari sekularisme itu sendiri (Tibi, 1998)

Hamas memperkenalkan dirinya sebagai "gerakan pembebasan dan perlawanan nasional Islam Palestina", dan Islam dijadikan sebagai kerangka rujukannya. Gerakan Hamas ini terbagi menjadi dua bidang yaitu gerakan di bidang sosial seperti pendidikan, dan gerakan di bidang militer dengan mewadahi gerakan massal rakyat Palestina. Terbaginya fokus dari gerakan Hamas tersebut terjadi karena pada masa sebelum dikeluarkannya piagam pada tanggal 18 Agustus 1988, gerakan al-Mujamma al-Islami 
belum berhasil membentuk masyarakat Palestina yang berilmu, oleh karena itu Hamas berkeinginan untuk membenahi kelemahan tersebut.

Strategi gerakan Hamas di Palestina mengalama tiga fase. Fase pertama, Hamas melakukan langkah awal dengan cara membangun pendirian yang kokoh supaya memperkuat "rantai selanjutnya" dalam sebuah organisasi dengan cara membentuk generasi yang kuat dan teruji. Fase kedua yang dialami oleh Hamas yaitu konflik nonmiliter dengan tentara pendudukan, dan fase terakhir yaitu gerakan jihad melawan kekuatan zionis israel. (Mikail, 2019)

Dari tiga fase umum yang dilakukan oleh Hamas ini menghasilkan beberapa pencapain yaitu berhasil menyekap seorang komandan Israel ,Ser May Nissim Toledano. Kemudian disusul dengan keberhasil pasukan berani mati yaitu Brigade al-qossam yang membunuh Direktur perumahan di jalur Gaza, Durron Susan. Perjuangan Hamas menggunakan senjata berkaitan erat dengan doktrin Jihad yang mereka pegang teguh, mereka meyakini bahwa " apabila musuh-musuh Allah datang kewilayah muslim untuk merampas hak-hak kemerdekaan mereka, maka penduduk tersebut dan seluruh muslim lainnya diwajibkan melawan" (Abu-Amr, 1993).

Ideologi yang dianut oleh Hamas juga berpengaruh kepada sistem kepemimpinan mereka, Hamas memiliki sistem kepemimpinan yang disebut Majelis Syuro. Sistem tersebut merupakan sistem kepemimpinan bersama yang terdiri dari satu pemimpin yang dipercaya dan dibantu oleh beberapa orang di majelis tersebut. Syaikh Ahmad Yassin yang saat itu menjalankan roda kepemimpinan yang dibantu oleh 6 orang majelis, mereka bersama-sama menjalankan kepemimpinan, mengeluarkan kebijakan politik, dan melakukan gerakan militer.

Hamas yang bermula dari gerakan perjuangan Palestina atau hanya sebuah organisasi saja, bertransformasi menjadi sebuah partai politik pada tahun 2005 yang ditandai dengan terlibatnya Hamas dalam pemilihan lokal yang pada akhirnya berhasil memenangkan parlemen pada tahun 2006. Gerakan yang secara de facto ini berhasil menguasai jalur gaza setelah berhasil mengalahkan presiden Palestina yaitu Mahmoud Abbas sejak tahun 2007. Ada beberapa hal yang membedakan Hamas dengan Fatah dan PLO, mereka memegang teguh pendirian bahwa "pendirian Israel sepenuhnya ilegal" (Irwan Abdallah, Setyawati, \& Mutiah, 2015).

\section{Ideologi dan Pergerakan Fatah}

Fatah merupakan salah satu partai politik yang paling dominan di Palestina, uniknya partai ini berdiri di Kuwait pada tahun 1959 yang dipelopori oleh sekelompok pengungsi Palestina yang memiliki ideologi nasionalis sekuler. Ideologi yang dianut membuat partai politik Fatah lebih memilih cara diplomasi dimeja perundingan dengan Israel dan mengurangi genjatan senjata yang mana bertolak belakang dengan cara Hamas. Sekularisme atau ideologi sekular banyak diartikan sebagai paham yang menolak ekstensi pengaturan sakral yang berasal dari suatu agama atau memisahkan politik dengan agama atau dengan aspek lainnya, menurut Auguste Comte hal itu dapat terjadi karena modernisasi (Pachoer, 2016). Pemahaman terhadap ideologi sekular tersebutlah yang membuat ideologi Islam tidak dapat menerima konsep sekular.

Struktur organisasi Fatah berbeda dengan Hamas, struktur tertinggi Fatah terdiri dari komite sentral, komite umum, dan dewan revolusi. Komite sentral merupakan cabang dari eksekutif Fatah yang membuat keputusan tertinggi, kemudian terdapat komite umum yang mana adalah parlemen dari Fatah yang menjadi otoritas tertinggi dari komite sentral, dan yang terakhir adalah dewan revolusi yang pada praktinya memiliki tugas sebagai jembatan pergerakan antara komite sentral dan komite umum (Bechor, 1991). 
Strategi pergerakan Fatah pada awalnya mengandalkan genjatan senjata sama halnya seperti yang dilakukan oleh Hamas, namun Fatah juga menempuh jalur diplomasi sebagai cara mereka untuk memperjuangkan Palestina. Fatah sendiri tidak sekeras Hamas yang sama sekali tidak mengakui adanya negara Israel, justru Fatah mengakui adanya negara Israel bahkan mereka sering melakukan perundingan.

Sebelum Fatah mengambil jalur diplomasi, dulu Fatah juga aktif dalam gerakan militer bersenjata yang dinamai al-Asifah, kelompok bersenjata ini mulai aktif bergerak pada tahun 1965, kelompok tersebut bermarkas di Tepi Barat, Gaza, dan di beberapa negara Arab lainnya. Al-Asifah mengawali perjuangan mereka dengan melawan kependudukan Israel dan terlibat dalam perang Arab-Israel 1967. Namun gerakan kelompok al-Asifah ini mengalami kegagalan setelah mereka terusir dari Yordania dan Lebanon, kemudian mereka mengalami pengusiran lagi pada tahun 1970-an dan 1980-an. (Rezasyah, 2019)

Setelah beberapa kali mengalami kegagalan maka al-Asifah dibawah naungan Fatah mengubah strategi perjuangan mereka dengan memilih jalur diplomasi untuk memperjuangkan kepentingannya. Namun bukan tanpa alasan Fatah memutuskan untuk mengambil langkah diplomasi, hal tersebut juga didukung oleh negara-negara Arab untuk lebih memilih jalur negosiasi setelah mereka terusir dari Beirut. Dengan demikian, maka Fatah melalui pemimpinnya yaitu Yasser Arafat menyatakan menghentikan dan bahkan melepaskan gencatan senjata dan mendukung resolusi 242 Dewan Keamanan PBB yang isinya mengantarkan Palestina kepada kepemilikan wilayah di Tepi Barat, Yerusalem Timur, dan Gaza pada tahun 1967.

Pada tahun selanjutnya Fatah berhasil mengendalikan PLO dan Yasser Arafat terpilih menjadi Ketua Komite Eksekutif, kemudian PLO yang dipimpin oleh Arafat berhasil diakui oleh negara-negara Arab pada KTT Rabat, kemudian diakui oleh PBB dan Israel dalam deklarasi Oslo sebagai perwakilan sah tunggal rakyat Palestina, berbagai pencapaian tersebut membuat Fatah menjadi gerakan yang dominan di Palestina.

\section{Konflik di Dalam Konflik: Hamas dan Fatah}

Dulu sebelum konflik antara Hamas dan Fatah meledak, kedua fraksi ini pernah menjalin kerja sama pada tahun 1967. Namun pada saat itu belum berdiri Hamas, melainkan Ikhwanul Muslimin (IM) di Palestina yang berjuang bersama-sama melawan Israel. Keduanya pernah bersatu untuk melawan segala bentuk penjajahan Israel terutama dengan genjatan senjata, namun gerakan Ikhwanul Muslimin (IM) lebih memilih untuk tidak terlibat perang, mereka lebih memilih untuk melakukan perubahan mendasar pada masyarakat Palestina, karena mereka percaya perubahan pada rakyat Palestina akan berdampak kepada perubahan politik Palestina yang lebih baik.

Oleh karena itu, urusan yang berkaitan dengan militer diserahkan kepada Fatah, karena Ikhwanul Muslimin lebih fokus kepada internal masyarakat Palestina dengan cara melakukan kegiatan dakwah, sosial, dan pendidikan. Fatah yang berfokus kepada kekuatan militer membuat pasukan yang diberi nama shaiks. Kerjasama ini hanya terjalin sampai tahun 1970-an karena adanya jurang pembeda dalam pemahaman dan sikap terhadap Israel (Bachtiar, 2006).

Dari penjelasan diatas dapat memberi jawaban mengapa Hamas dan Fatah tidak bekerjasama, selain karena perbedaan ideologi ternyata ada faktor sejarah didalamnya, dapat disimpulkan bahwa jauh sebelum Hamas terbentuk, gerakan Ikhwanul Muslimin yang merupakan akar dari berdirinya Hamas di Palestina sudah lebih dulu melakukan kerjasama dengan Fatah walaupun pada akhirnya memutuskan untuk berjalan sendiri- 
diri, oleh karena itu tidak heran jika setelah berdirinya Hamas pada tahun 1987, mereka tidak melakukan kerja sama dengan Fatah walaupun keduanya memiliki tujuan yang sama, karena Hamas yang merupakan titisan dari Ikhwanul Muslimin di Palestina sudah mengetahui bahwa mereka memiliki jurang perbedaan dengan Fatah dan hal itu sudah dirasakan oleh pendahulunya.

Konflik antara Hamas dan Fatah mulai muncul kepermukaan pada tahun 2005 setelah kematian Yasser Arafat pada tahun 2004, kemudian ketegangan antara keduanya kembali muncul pada tahun 2006 setelah Hamas berhasil menang dalam pemelihan umum yang membuat mereka mendominasi kursi di Parlemen dan menyebabkan Fatah kehilangan dominasinya di Parlemen. Kekuasaan yang dipegang oleh Hamas membuat mereka bisa mengambil paksa kendali atas Jalur Gaza yang dipegang oleh Fatah pada tahun 2007, kemudian Hamas dengan mudahnya memindahkan petugas PA dari Jalur Gaza (Ferry, Hamas-Fatah: Jejak Perang Saudara Satu Dekade Sebelum Damai, 2017).

Mengetahui ada hal yang tidak baik antara Hamas dan Fatah membuat presiden Palestina yaitu Mahmoud Abbas harus mengambil tindakan dengan menggulingkan pemerintahakan PA yang dikendalikan oleh Hamas, kemudian Mahmoud Abbas membagi kendali atas kedua wilayah tersebut, yaitu Hamas ditempatkan di Jalur Gaza dan Fatah ditempatkan di Tepi Barat.

Konflik antara Fatah dan Hamas tidak semata-mata berasal dari masalah internal saja namun ada beberapa faktor luar yang mendorong seperti adanya blokade ekonomi dan militer yang dikeluarkan oleh Amerika dan Israel terhadap Palestina sebab Hamas menembakan roket dan mortir ke gedung-gedung sipil Israel di Jalur Gaza. Kemudian kedua fraksi ini memiliki perbedaan dari suplai senjata, Hamas menerima suplai senjata dari Iran sedangkan Fatah mengambil senjata dari gudang senjata milik Israel, ditambah dengan beredarnya isu bahwa pemimpin Fatah dikendalikan oleh Amerika pada usaha damai tahun 2010 di Damaskus.

Beberapa pihak menyayangkan konflik yang terjadi antara Hamas dan Fatah, seperti yang disampaikan oleh Direktur Eksekutif Pusat Nasional untuk Rehabilitasi Masyarakat Palestina, yaitu Fatma A. Al-Gussain mengatakan bahwa konflik tersebut tidak memberikan dampak baik terhadap Palestina, ditambah dengan kondisi Palestina yang sudah buruk karena penguasaan wilayah Palestina oleh Israel (Pratiwi, 2018).

\section{Gerakan Persatuan Palestina}

Pada tahun 2017, menjadi tahun yang bersejarah bagi cerita panjang gerakan perjuangan Fatah dan Hamas karena akhirnya setelah mengalami konflik selama hampir 11 tahun mereka memutuskan untuk melakukan rekonsiliasi. Keputusan tersebut direspon dengan sangat baik oleh presiden Palestina yaitu Mahmoud Abbas melalui pernyataan dari Duta Besar Palestina untuk Indonesia, Zuhair Al Shun. Ia menyampaikan bahwa "Presiden sendiri ingin permasalahan tersebut selesai dan kita bersatu kembali dari segala sisi".

Respone baik juga muncul dari negara-negara tetangga Palestina dikawasan Arab yang memberikan bantuan untuk tercapainya rekonsiliasi tersebut, seperti Mesir yang menjadi mediator kedua fraksi tersebut. Rekonsiliasi antara Fatah dan Hamas mempunyai maksud untuk kebaikan Palestina itu sendiri, masyarakat berharap dengan membaiknya hubungan kedua gerakan perjuangan yang paling dominan di Palestina tersebut dapat menyelesaikan permasalahan Palestina bersama-sama di meja perundingan.

Sebelum kesepakatan rekonlisiasi Fatah dan Hamas terwujud, kedua fraksi ini sempat melakukan usaha rekonsiliasi pada tanggal 9 November 2010 di Damaskus, Suriah. Perwakilan dari Hamas dan Fatah dipertemukan untuk melakukan perundingan 
dengan tujuan mempersempit perbedaan diantara mereka, dalam perundingan tersebut mereka akan berfokus kepada bahasan pengendali aparat Palestina, karena kendali wilayah Palestina terbagi menjadi dua, yaitu Jalur Gaza yang dikuasai oleh Hamas dan Tepi Barat oleh Fatah.

Pada perundingan ini dihadiri oleh pejabat senior Fatah yaitu Majid Farah dan Hamas yang diwakili oleh orang nomor dua Hamas yaitu Moussa Abu Marzouk. Dalam perundingan ini keduanya sepakat untuk memilih Mesir sebagai negosiator mereka dalam proses rekonsiliasi. Sebenarnya pembicaraan mengenai rekonsiliasi ini dijadwalkan pada bulan Oktober namun terjadi kendala karena Bashar al-Assad melontarkan komentarkomentar panas di KTT Arab mengenai isu perlawanan terhadap Israel. Selain itu, Iran dan Suriah yang mendukung dan berpihak kepada Hamas saling bekerja sama untuk mendapatkan kembali Dataran Tinggi Golan yang dikuasai oleh Israel.

Dengan terlibatnya aktor-aktor eksternal seperti Amerika Serikat yang mendukung konflik antara Hamas dan Fatah menarik keterlebitan negara lain seperti Suriah, Iran, dan Mesir untuk membantu menyelesaikan konflik antara Hamas dan Fatah yang mana akan berpengaruh pada kondisi politik internal Palestina itu sendiri (Palupi, 2010). Dalam proses hingga kesepatan rekonsiliasi Fatah dan Hamas terwujud, ada peran Mesir didalamnya. Mesir berperan sebagai mediator, bukan tanpa alasan Mesir memutuskan untuk terlibat dalam permasalahan ini, hal tersebut berkaitan dengan isu keamanan Mesir yang berbatasan dengan Jalur Gaza.

Pada kesepatan rekonsiliasi antara Hamas dan Fatah menghasilkan beberapa kerjasama seperti kerjasama keamanan dan kesepakatan bahwa pemilihan presiden, dewan pemilihan nasional, dan legislatif akan dilakukan satu tahun yang akan datang setelah penandatanganan. Dengan kesepakatan rekonsiliasi antara Hamas dan Fatah membuat rakyat Palestina berharap bahwa mereka dapat memperbaiki kondisi kemanusian di Palestina yang tergantung kepada bantuan makanan karena blokade yang dilakukan oleh Israel.

\section{KESIMPULAN}

Hasil penelitian ini menunjukan bahwa ideologi bukan satu-satunya penyebab dan masalah utama Hamas dan Fatah tidak bekerja sama untuk membebaskan Palestina dari pendudukan Israel, namun terdapat faktor konflik sejarah dari pendahulu Hamas yaitu Ikhwanul Muslimin di Palestina, bahwa Fatah dan Ikhwanul Muslimin (IM) pernah berjuang bersama untuk melawan Israel di Palestina yang kemudian berpisah karena perbedaan fokus Ikhwanul Muslimin yang lebih memperbaiki kualitas masyarakat Palestina dengan memberi mereka pendidikan dan memilih untuk tidak terlibat perang, sedangkan Fatah pada saat itu masih menggunakan kekuatan militernya untuk melawan Israel, karena perbedaan tersebut akhirnya Fatah dan Ikhwanul Muslimin (IM) memutuskan untuk berjuang membela Palestina dengan caranya masing-masing, Ikhwanul Muslimin terus berjuang membela Palestina yang pada akhirnya dititiskan kepada Hamas, yang kemudian setelah Hamas berdiri tidak ada hubungan kerja sama lagi dengan Fatah karena pendahulu mereka yaitu Ikhwanul Muslimin (IM) pernah mengalami hal terbut dan Hamas mengetahui perbedaan yang dimiliki antara Hamas dan Fatah dari pendahulunya.

Kemudian terdapat faktor-faktor lain yang menyebabkan jurang perbedaan Hamas dan Fatah semakin membesar, yaitu : (1) Faktor mendasar adalah perbedaan ideologi yang dimiliki kedua fraksi, Hamas dengan ideologi Islam sedangkan Fatah dengan ideologi 
sekular, yang mana ideologi tersebut saling berlawanan. (2) Fatah menandatangani kesepakatan dengan Israel dalam Deklarasi Oslo yang dianggap oleh Hamas sebagai bentuk pengakuan Palestina akan adanya negara Israel yang mana pengakuan tersebut bertentangan dengan prinsip Hamas, (3) isu korupsi dan penyelewengan kekuasaan yang dilakukan oleh Fatah pada Deklarasi Oslo II, (4) dan perbedaan pandangan dalam menyikapi perlawanan Israel, Hamas memilih bergilya dengan mengangkat senjata sedangkan Fatah lebih memilih jalur diplomasi di meja perundingan dengan Israel.

Tekanan ideologi Hamas dan Fatah dalam membebaskan Palestina dari pendudukan Israel membuat kondisi internal Palestina goncang, ideologi keduanya juga berpengaruh terhadap cara bagaimana mereka menyikap masalah dan menyelesaikan masalah, namun jurang perbedaan tersebut terus dipersempit dengan melakukan rekonsiliasi yang dimediatori oleh Mesir. Pada tahun 2017, Hamas dan Fatah menandatangani kesepakatan rekonsiliasi di Mesir yang disambut baik oleh pemerintahan dan rakyat Palestina, mereka berharap dengan bersatunya kedua fraksi yang paling dominan di Palestina tersebut dapat menyelesaikan konflik antara Palestina dengan Israel. 


\section{DAFTAR PUSTAKA}

Bachtiar, T. A. (2006). Hamas, kenapa dibenci Amerika? Jakarta: Hikmah.

Bechor, G. (1991). Lexicon of The PLO. Tel Aviv: The Ministry of Defense.

Burdah, I. (2008). Konflik Timur Tengah: Aktor, Isu dan Dimensi Politik. Yogyakarta: Tiara Wacana.

Deutsch, M., Coleman, P. T., \& Marcus, E. C. (2006). The Handbook of Conflict Resolution. Dalam E. A. Weitzman, \& P. F. Weitzman, The PSDM Model: Integrating Problem Solving and Decision Making in Conflict Resolution (hal. 197-221). San Francisco: Jossey-Bass.

Dewi, I. M., Sudrajat, A., \& Miftahuddin. (2008). Gerakan Rakyat Palestina: Dari Deklarasi Negara Israel Sampai Terbentuknya Negara Palestina. Yogyakarta: Universitas Negeri Yogyakarta.

Diani, M. (1992). The concept of social movement. The Sociological Review.

Fatimah, S., \& Syukur, Y. (2019). Al-Qaeda's New Orientation After the Death of Osama bin Laden. Jurnal Studi Sosial Dan Politik, 3(2), 130-145. https://doi.org/https://doi.org/10.19109/jssp.v3i2.4390

Ferry, O. (2017, Oktober 13). Hamas-Fatah: Jejak Perang Saudara Satu Dekade Sebelum Damai. Dipetik Oktober 26, 2019, dari CNN Indonesia: https://www.cnnindonesia.com/internasional/20171013015049-120248096/hamas-fatah-jejak-perang-saudara-satu-dekade-sebelum-damai

Ferry, O. (2017, Oktober 13). Hamas-Fatah: Jejak Perang Saudara Satu Dekade Sebelum Damai. Dipetik Desember 9, 2019, dari CNN Indonesia: https://www.cnnindonesia.com/internasional/20171013015049-120248096/hamas-fatah-jejak-perang-saudara-satu-dekade-sebelum-damai

Irwan Abdallah, S., Setyawati, \& Mutiah, S. (2015). IDEOLOGI HAMAS GERAKAN PERLAWANAN ISLAM. Jurnal CMES, 101-107.

MikailK. (2018). Iran's Nuclear Deal and Its Influence on USA-Israel's Interest in the Middle East. Jurnal ICMES, 2(1), 69-85. https://doi.org/10.35748/jurnalicmes.v2i1.1

Mokhtari, M. (2019). A Study on the Social Movements in Contemporary Islamic Thought. Jurnal Studi Sosial Dan Politik, 3(2), 114-129. https://doi.org/https://doi.org/10.19109/jssp.v3i2.4389

Pachoer, R. D. (2016). Sekularisasi dan Sekularisme Agama. Religious: Jurnal Agama dan Lintas Budaya, 91-102.

Palupi, W. T. (2010). Hamas-Fatah Rekonsiliasi. Jakarta: Internasional Republika.

Prabowo, W. (2013). Hamas: Death or Freedom. Yogyakarta: Palapa.

Pruitt, D. G., \& Rubin, J. Z. (2009). Teori Koflik Sosial. Yogyakarta: Pustaka Pelajar.

Rezasyah T. (2019). The Role of Indonesian Diplomats in Supporting Palestinian's Struggle at the UN (in the Time of Presidency of the UNSC, May 2019). Jurnal ICMES, 3(2), 122-136. https://doi.org/10.35748/jurnalicmes.v3i2.55

Santis, Y. (2008). Hamas: Its Ideologi and Record. San Francisco: Jewish Community Relations Council.

Tibi, B. (1998). The Challenge of Fundamentalisme Political Islam and the New World Disorder. California: (University of California Press) Cet. 1. 